\title{
Review of National Park Science: A Century of Research in South Africa by Jane Carruthers
}

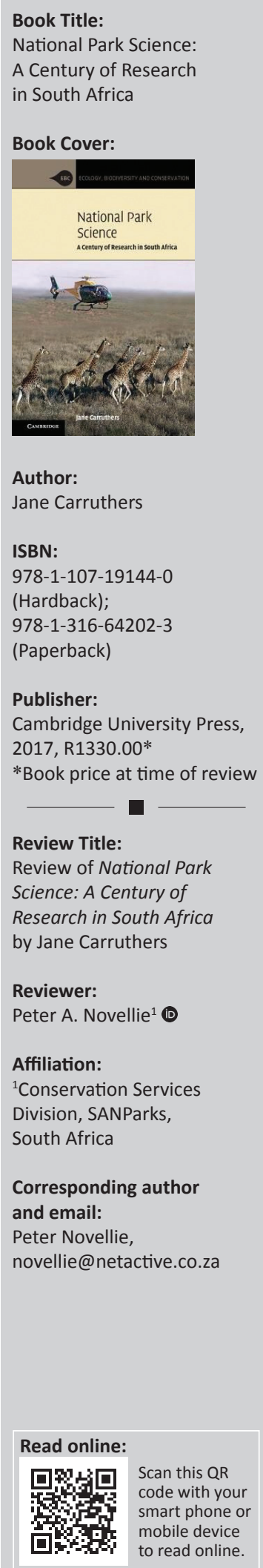

From the perspective of a long-serving scientist - initially of the National Parks Board, later SANParks - Jane Carruthers' book took me on an enchanting and insightful journey. I could readily recognise - and at least partly recollect - the three periods into which she divides the historical narrative, each named in accordance with the prevailing nature conservation paradigm: protecting, preserving and propagating (1900-1960); measuring, monitoring and manipulating (1960-1990); and integration, innovation and internationalisation (1990-2010). The analysis is wide-ranging and thoroughly grounded in numerous sources. Particularly, the first and second of the three periods are enriched by many years of research on environmental history and conservation, including a focus on the social and political history of the Kruger National Park, as well as other protected areas.

Good scholarship stimulates new ideas, introduces fresh perspectives and alters mindsets. Carruthers has achieved this in ways that raise important questions for further analysis. As I travelled through the narrative, with its intriguing reminders of paradigms, institutions and personalities of distant eras, I was struck by my own career-long disregard for the past. I found I had a partial and imperfect knowledge of the contributions of older scientific colleagues whose period of service overlapped mine, and knew little or nothing of those, notably P.J. Barnard and T.G. Nel, who had departed before my time. During my early years in the organisation, I was dismissive of the work of predecessors of long before. This perspective, as Carruthers explains in her preface, is typical of scientists who are trained to feel that there is no point in reading anything but the latest paper. Scientists assume that the present includes all pasts, and tend to be impatient with historical context, whereas environmental historians must read all papers to unpack intellectual journeys in light of their political and social contexts (Carruthers 2017:xxiv). By the end of the book, I was convinced that an understanding of past journeys, and their contexts, is as important for conservation scientists as it is for historians.

Like all organisations, SANParks and its predecessor, the National Parks Board, developed organisational pride - undoubtedly a healthy phenomenon, but which can decline into unwarranted self-congratulation, based on historical half-truths, even outright myths. One long-held myth that Kruger was South Africa's first national park - Carruthers exposes as false. The 1960s-1990s were characterised by an element of arrogance and isolationism, convictions that 'we know best', and resistance to external influences save those of a select group of trusted collaborators. Carruthers indicates how the attitude of this time was not only self-delusional (science in the National Parks Board was actually behind the times) but also hampered scientific progress. For example, the organisation was extraordinarily slow to embrace the concept of biodiversity. The analysis of publications in the journal KOEDOE showed that the word 'biodiversity' appeared only in 1999 'as a keyword for a contribution relating to national parks - almost 20 years after it had entered the lexicon of conservation biology' (Carruthers 2017:209). Scientific stagnation was swept away during the period of integration, innovation and internationalisation that followed. Political and social transformation in South Africa and the world promoted receptivity to new ideas and stimulated the growth of science in national parks.

Thus, a significant achievement of the book is its analysis of the complex transitions between the three periods, the external developments that influenced and facilitated the transitions, and the processes whereby old ways of thinking were replaced by new ideas. Such transitions are in the nature of conservation organisations and SANParks will undoubtedly undergo others in future. A body of theories is developing on how the governance of socio-ecological systems can be transformed from inflexible 'command and control' approaches to adaptive governance

How to cite this book review: Novellie, P.A., 2018, 'Review of National Park Science: A Century of Research in South Africa by Jane Carruthers', Koedoe 60(1), a1550. https://doi.org/10.4102/koedoe.v60i1.1550

Copyright: @ 2018 . The Authors. Licensee: AOSIS. This work is licensed under the Creative Commons Attribution License. 
regimes (e.g. Olsson et al. 2006). It could be insightful to examine Carruthers' account of the transition to integration, innovation and internationalisation in light of this theory.

Importantly, Carruthers draws attention to several longstanding problem areas that have remained intransigent, at variance with the flow of transition in national park science. These remain evident to this day. There is no obvious explanation for the shortcomings, and one feels that they merit further investigation. One of the long-standing problem areas is the neglect of the humanities and social sciences in general. The absence of staff members qualified in these fields meant that studies have often been undertaken by untrained people (Carruthers 2017:417). Richard Bell, in his 1995 report on the state of scientific services in the Kruger National Park, recommended the employment of social scientists. The recommendation went unheeded for many years, and Carruthers indicates that the dearth of publications in the humanities, in both Kruger and the other national parks, was evident throughout the period covered by her book. A possibly related problem area is the ineffectiveness and limited impact of the Social Ecology Unit of SANParks (Carruthers 2017:343), all the more surprising in view of the urgency of reaching out to the historically marginalised communities surrounding national parks. The neglect of social sciences relative to biophysical sciences is not limited to national parks in South Africa; it has been reported elsewhere in the world (Bennett et al. 2016; Correia et al. 2016; Moreno et al. 2014).

Another persistent shortcoming is that of 'silos', a lack of collaboration between the National Parks Board/SANParks and other South African conservation agencies or institutions. As indicated above, isolationism was a particular feature of the 1960s-1990s, but Carruthers notes that the lack of collaboration with provincial conservation agencies persisted even into the period of integration, innovation and internationalisation (Carruthers 2017):

fewer silos and more synergy and collaboration would lead to further integration, innovation and internationalisation to the benefit of conservation science in South Africa, and particularly to good and meaningful research in the smaller national parks and protected areas. (p. 464)

During my final years with SANParks, the Department of Environmental Affairs repeatedly encouraged collaboration and assistance for particularly certain provincial conservation authorities. It seems worth reflecting why this has been an enduring problem area.

A peculiar phenomenon uncovered by Carruthers is the apparent discomfort in the National Parks Board/SANParks with the idea of scientific advisory boards. There was a succession of efforts to provide expert scientific oversight for national parks and other protected areas, starting as early as the 1940s and the 1950s, continuing during the 1980s with the National Committee for Nature Conservation (NACOR) and finally, in the mid-1990s, an offer of financial support from the Mellon Foundation for a guiding body of international scientists. All these efforts came to nothing.

Carruthers highlights another persistent feature of South Africa's system of protected areas - its misalignment with the International Union for Conservation of Nature (IUCN) system of classifying protected areas. Harold Eidsvik's 1996 report on national parks pointed out that some did not qualify as such in terms of the criteria of the day. The Protected Areas Act of 2003 ignored the IUCN classification, and SANParks continues to manage parks such as Bontebok, which do not qualify.

A serious problem area is the long-standing discrepancy in research capacity and output between Kruger and the other national parks. This is apparent from the numbers of publications from each national park from 2012 to 2016 (Carruthers 2017:447-448). An aspect that remains to be clarified is the extent to which the achievement of the conservation objectives set in park management plans may have been compromised in the poorly researched parks. Carruthers draws attention to the potential for collaboration and partnerships with other conservation agencies and universities. However, collaboration by itself does not provide a ready solution to the imbalance between parks because the research community is strongly biased towards the larger and older national parks (Van Wilgen et al. 2016). This is not a uniquely South African phenomenon; Correia et al. (2016) show that the larger, older and more protected reserves in Ecuador and Peru were more likely to have high scientific production. It appears that the potential of a park to deliver science outputs will be influenced by inherent, 'given' features - such as size and age - that are beyond the control of management (Smit et al. 2017) and do not bear any relationship with the need for research as a guide to realise conservation objectives. Smit et al. (2017) suggest that this bias can be mitigated by various measures designed to attract research collaboration.

An influence that looms large in my recollection of 32 years with national parks, but which seems understated in the book, is the provision in both the National Parks Act of 1976 and the Protected Areas Act of 2003 for the organisation to retain self-generated income. Its influence was not only a feature of the era of integration, innovation and internationalisation (Carruthers 2017:368-369); it was apparent from the 1980s. It empowered the National Parks Board/SANParks and gave it financial flexibility, but I have the feeling that it may have contributed, directly or indirectly, to some of the problem areas outlined above. It engendered an organisational pride in partial independence of the national fiscus, understandably more among staff members responsible for income generation than among scientists. It introduced a degree of cynicism, often diplomatically hidden but nevertheless prevalent, regarding expenditure on enterprises that do not generate income. This attitude probably constrained significant investments in new fields, however deserving, such as staff qualified in the social sciences, outreach to communities 
through Social Ecology, or on collaboration and support for needy provincial conservation authorities.

Arguably perhaps, it may also account for the apparent discomfort with scientific advisory boards, whose recommendations would often beat variance with the main financial drivers of the organisation. I remember being sent to attend National Committee for Nature Conservation (NACOR) meetings because it was politic for the National Parks Board to show face at that forum, knowing well that my organisation had its own agenda for park expansion and had no intention of following NACOR priorities. This agenda prioritised park expansion to enhance 'big five' ecotourism prospects, so as to extend the Kruger model of income generation to other parks. This is entirely understandable in view of the provisions of the National Parks Act, which gave the Parks Board stronger potential to fund land acquisition than NACOR could provide.

Dependence on self-generated income also means that 'money source' parks (notably Kruger) subsidise other parks, the 'money sinks'. Some of the provincial conservation agencies came to adopt financing models similar to that of SANParks. This makes it very difficult to align South African protected areas with the IUCN classification and explains why Bontebok National Park has remained in the SANParks estate. Financial viability requires a balance between money sources and money sinks, and no one is keen to take on the sinks. Measures to attract research collaboration, such as providing and servicing research accommodation, are undoubtedly easier to establish in 'money source' parks, and it will require innovative approaches to attract collaborators to the money sinks.

Clearly SANParks' financial resources allow only limited improvements to science capacity, and initiatives are needed to access additional funding sources. Carruthers' account of the role of the Mellon Foundation, and of other donors, provides a valuable record of how helpful such sources can be in strengthening science capacity. It is important to understand how SANParks came to exploit windows of opportunity in accessing such funding sources. A vital link in this process does not feature in the book, namely the initiative of middle level scientists who engaged with key individuals in funding organisations to identify opportunities and who convinced their superiors in SANParks of the potential of these opportunities. A few individual scientists in SANParks have been influential in brokering access to important sources of financing. These initiatives are undocumented, least of all in the job descriptions of the scientists involved, and so are easily overlooked.

Carruthers' history of science in national parks not only recognises significant and valuable achievements but is most valuable for a critical and sometimes unflattering analysis and for highlighting key questions for further investigation. In recent years, SANParks scientists have entered a new phase, embracing new theoretical principles to manage complex, multi-actor socio-ecological systems. These include broadening participation and collaboration to harness diversity, social learning as concerted action, adaptive governance as a prerequisite for adaptive management and the value of transdisciplinarity. Carruthers' emphasis on collaborative research, and on understanding past intellectual journeys and their contexts, resonates well with these new principles. Her work is an essential reading for SANParks scientists embarking on the new phase of science.

\section{References}

Bennett, N.J., Roth, R., Klain, S.C., Chan, K., Christie, P., Clark, D.A. et al., 2016, 'Conservation social science: Understanding and integrating human dimensions to improve conservation', Biological Conservation 205, 93-108. https://doi.org/ to improve conservation', Biol
$10.1016 / \mathrm{j}$.biocon.2016.10.006

Carruthers, J., 2017, National Park Science: A Century of Research in South Africa, Cambridge University Press, Cambridge, United Kingdom.

Correia, R.A., Malhado, A.C.M., Lins, L., Gamarra, N.C., Bonfim, W.A.G., Valencia Aguilar, A. et al., 2016, 'The scientific value of Amazonian protected areas', Biodiversity and Conservation 25(8), 1503-1513. https://doi.org/10.1007/s10531-016-1122-x

Moreno, J., Palomo, I., Escalera, J., Martín-López, B. \& Montes, C., 2014, 'Incorporating ecosystem services into ecosystem-based management to deal with complexity: A participative mental model approach', Landscape Ecology 29, 1407-1421. https:// doi.org/10.1007/s10980-014-0053-8

Olsson, P., Gunderson, L.H., Carpenter, S.R., Ryan, P., Lebel, L., Folke, C. et al., 2006, 'Shooting the rapids: Navigating transitions to adaptive governance of socialecological systems', Ecology and Society 11(1), 18, viewed 12 July 2018, from http://www.ecologyandsociety.org/vol11/iss1/art18/

Smit, I.P.J., Roux, D.J., Swemmer, L.K., Boshoff, N. \& Novellie, P., 2017, 'Protected areas as outdoor classrooms and global laboratories: Intellectual ecosystem services flowing to-and-from a National Park', Ecosystem Services 28, 238-250. http://doi. org/10.1016/j.ecoser.2017.05.003

Van Wilgen, B.W., Boshoff, N., Smit, I.P.J., Solano-Fernandez, S. \& van der Walt, L., 2016, 'A bibliometric analysis to illustrate the role of an embedded research capability in South African National Parks', Scientometrics 107, 185-212. https:// doi.org/10.1007/s11192-016-1879-4 